\title{
DATING HUMAN REMAINS FROM THE HISTORICAL PERIOD IN BELGIUM: DIET CHANGES AND THE IMPACT OF MARINE AND FRESHWATER RESERVOIR EFFECTS
}

\author{
Anton Ervynck ${ }^{1,2} \bullet$ Mathieu Boudin ${ }^{3}$ Tess van den Brande ${ }^{3}$ Mark Van Strydonck

\begin{abstract}
An overview will be presented of stable isotope data $\left(\delta^{13} \mathrm{C}\right.$ and $\left.\delta^{15} \mathrm{~N}\right)$ available from animal and human bones from Roman to post-Medieval Belgian sites. The data will be used to assess trends in the human diet and evaluate the possible impact of reservoir effects originating from the consumption of fish derived from marine or freshwater environments. Historical and archaeozoological data demonstrate drastic changes in fish consumption throughout the last 2 millennia and thus suggest that fluctuations through time of the impact of the reservoir effects can be expected. However, the present stable isotope data set does not support this suggestion.
\end{abstract}

\section{INTRODUCTION}

The radiocarbon dating of human remains is a vital step in archaeological projects dealing with the historical period (mainly the 1st and 2nd millennium AD) in northwest Europe because, since the onset of Christian burial traditions, graves usually no longer include artifacts that can be used as chronological indicators. In that respect, it is essential to make sure that the ${ }^{14} \mathrm{C}$ dates obtained are not affected by so-called reservoir effects, resulting from the inclusion of food products in the human diet, derived from environments with a lower ${ }^{14} \mathrm{C}$ content than is the case in the atmosphere (Stuiver and Braziunas 1993).

In Belgian archaeology, ${ }^{14} \mathrm{C}$ dates obtained from human remains generally seem not to be affected by reservoir effects. This is an empirical statement, but it is corroborated by cases in which skeletons from persons with a historically known date of death are dated. An example is provided by a certain Vulferus, buried and excavated at Ghent, who had an endotaph in his grave, a stone with an inscription mentioning that he died in the year $\mathrm{AD} 1013$. The ${ }^{14} \mathrm{C}$ date obtained was $1050 \pm 20$ BP (Boudin and Van Strydonck 2010, KIA-21809), calibrated to AD 900-920 (3.8\% probability) or AD 960-1030 (91.6\% probability) (all dates calibrated following OxCal v 3.10 [Bronk Ramsey 2001] with IntCal09 atmospheric data [Reimer et al. 2009]). Another example is provided by the relic of Saint-Bavo, historically known to have died after AD 651-655 but before AD 659, showing a ${ }^{14} \mathrm{C}$ date of $1410 \pm 25 \mathrm{BP}$ (calibrated to AD 600-655 with 95.4\% probability) (Van Strydonck et al. 2006). In contrast, recent excavations in the cemetery of Slijpe (province of West-Flanders) yielded a ${ }^{14} \mathrm{C}$ date of $1075 \pm 30 \mathrm{BP}$ (KIA-47728, calibrated to AD $890-1020,95.4 \%$ probability) for a human skeleton buried in a coffin of beech wood (Fagus sylvatica), producing two dendrochronology dates: after AD 1083 and after AD 1105 (Smet et al. 2012). This observation forms a warning that reservoir effects still could be an issue, and that their possible effects should be evaluated.

When dealing with archaeological human remains from Belgium dating from the Roman and younger periods ( $\sim 57 \mathrm{BC}$ to today), the consumption of both marine and freshwater fish has to be taken into account. Consumption of these aquatic organisms is well documented by archaeozoological research, and drastic changes in consumption patterns through time have been demonstrated, with little or no consumption of this animal group in Roman times ( $\sim 57 \mathrm{BC}$ to 4th century AD) (Van Neer et al. 2010) (most probably a continuation of consumption patterns from the Iron Age: Dobney and Ervynck 2007), followed by the consumption of fish mostly caught in freshwater environments

1. Flanders Heritage Agency, Koning Albert II-laan 19 box 5, B-1210 Brussels, Belgium.

2. Corresponding author. Email: anton.ervynck@rwo.vlaanderen.be.

3. Royal Institute for Cultural Heritage, Jubelpark 1, B-1000 Brussels, Belgium.

Proceedings of the Radiocarbon and Archaeology 7th International Symposium Ghent, Belgium, April 2013 | Edited by Mark Van Strydonck, Philippe Crombé, and Guy De Mulder (C) 2014 by the Arizona Board of Regents on behalf of the University of Arizona 
during the Early Middle Ages (5th-9th century AD), and a rise of marine fish consumption starting from the 10th century AD, accompanied by a loss of importance for freshwater fish (Ervynck et al. 2004; Van Neer and Ervynck 2006). The rise of marine fish consumption is characterized by the initial exploitation of coastal waters and a subsequent shift of fishing grounds to more open and northern waters. This trend is reflected in the archaeozoological collections from consumer sites by a growing importance of gadids (Gadidae) versus herring (Clupea harengus) and flatfish (Pleuronectidae), and, within the gadids, a shift towards cod (Gadus morhua) instead of haddock (Melanogrammus aeglefinus) and whiting (Merlangius merlangus) (Van Neer et al., in press). The freshwater fish consumed through time are mainly eel (Anguilla anguilla) and cyprinids (Cyprinidae, including, from the 13th century onwards, domestic carp [Cyprinus carpio f. domestica]). Historical and iconographical sources corroborate the rise of importance of seafish consumption since the beginning of the 2nd millennium AD (Asaert 1980; Boelmans Kranenburg 1979, 1980; Van Uytven 1979). In contrast to the marked trends in fish consumption, archaeological and historical evidence points towards a continuous use of coastal mollusks in Roman to post-Medieval diets (Ervynck et al. 2004; Van Neer and Ervynck 2006).

Fluctuations through time of the impact of reservoir effects linked with fish consumption should thus be expected. Food products derived from the North Sea should show a marine reservoir effect of $\sim 400 \mathrm{yr}$ (see Stuiver and Braziunas 1993), but, unfortunately, the reservoir effect of the different streams belonging to the three river basins in Belgium (i.e. the Yser, Scheldt, and Meuse basins) remains unknown. For other freshwater environments in northwestern Europe, estimates vary from several hundred to thousand years (Lanting and van der Plicht 1998; Fischer and Heinemeier 2003). For Belgium, the lack of information on freshwater reservoir effects also hampers any estimation of the (intermediate?) reservoir effect in food products found in brackish waters (e.g. in estuaries or creeks near the coast) and in species that were migrating between marine and freshwater environments.

The contribution of freshwater and marine fish to the former human diet can be evaluated through the analysis of stable isotopes $\left(\delta^{13} \mathrm{C}\right.$ and $\left.\delta^{15} \mathrm{~N}\right)$ from excavated skeletons or otherwise preserved human remains (see Lee-Thorp 2008 for a review). Of course, this approach is based upon the assumption that the stable isotope signals in the aquatic food products consumed are significantly different from those in terrestrial organisms, and between freshwater and marine species. An assessment of the $\delta^{13} \mathrm{C}$ and $\delta^{15} \mathrm{~N}$ signals from the skeletal remains of a variety of fish species, and of a number of terrestrial domestic mammals, consumed at Medieval and post-Medieval inland sites located in the Scheldt Basin (Fuller et al. 2012; Quintelier et al. 2014), proves that the expected differences are indeed present (Figure 1). Shifts in the stable isotope values of the human skeletal remains from archaeological sites dating from Roman to post-Medieval times should thus also be expected, and their evaluation could warn against the impact of reservoir effects.

This article will present an overview of stable isotope data $\left(\delta^{13} \mathrm{C}\right.$ and $\left.\delta^{15} \mathrm{~N}\right)$ available from animal and human bones from Roman to post-Medieval Belgian sites. The data will be used to assess trends in the human diet and evaluate the possible impact of reservoir effects.

\section{MATERIAL AND METHODS}

For the human data set, stable isotope data $\left(\delta^{13} \mathrm{C}\right.$ and $\left.\delta^{15} \mathrm{~N}\right)$ have been collected from bones subjected to ${ }^{14} \mathrm{C}$ dating in the Royal Institute for Cultural Heritage (KIK), over the last decades. The composition of the human data set has thus not been controlled but almost exclusively represents adult individuals from both sexes, from (regionally and chronologically) different populations within Belgium. For the Roman period (1st to 4th century AD), data are scarce given the dominant prac- 


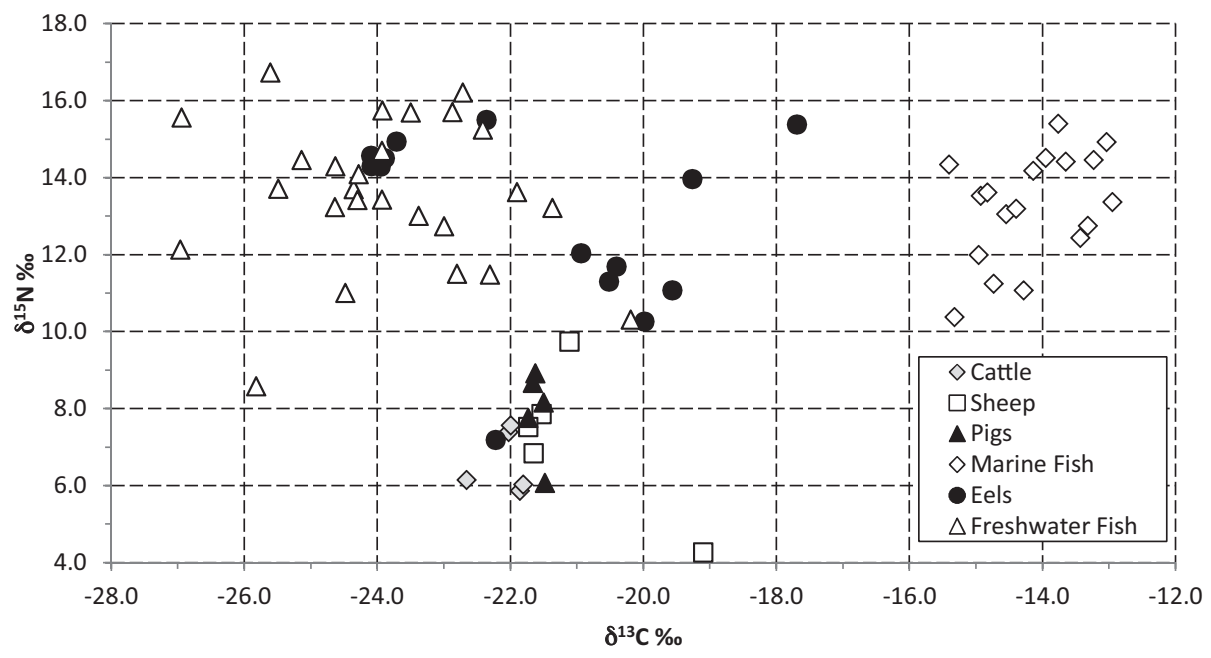

Figure 1 Stable isotope $\left(\delta^{13} \mathrm{C}\right.$ and $\left.\delta^{15} \mathrm{~N}\right)$ data for fish and terrestrial domestic mammals from archaeological sites in the Scheldt Basin, Belgium (after Fuller et al. 2012; Quintelier et al. 2014). Marine fish included sturgeon, shad, plaice, flounder, flatfish, halibut, herring, haddock, whiting, and cod; freshwater fish included roach, ide, tench, carp, pike, and cyprinids.

tice of cremating the deceased before burial, at that time. Skeletal remains from the Early Middle Ages are also scarce in Belgian archaeology, but samples for that period have been obtained from Christian relics, i.e. bones from local saints, that were ${ }^{14} \mathrm{C}$ dated as part of a historical research project (Van Strydonck et al. 2006, 2009). While specimens from the 11th century AD onwards are amply represented in the data set, very recent material (after AD 1500) is again scarcer, given the fact that such finds are not often selected for ${ }^{14} \mathrm{C}$ dating. In total, 234 humans were included in the study population. Their lab code, provenance, and ${ }^{14} \mathrm{C}$ and isotope data are listed in the online-only supplemental file (Table S1). More information on the specimens can be found on the website of the KIK-IRPA lab (http://c14.kikirpa.be, Van Strydonck and De Roock 2011).

A similar approach was followed for the composition of a data set for terrestrial domestic mammals (i.e. sheep, pig, cattle, horse, and rabbit). The 107 specimens again represent a variety of locations and time periods. Their lab code, provenance, ${ }^{14} \mathrm{C}$ and isotope data are listed in an online-only supplemental file (Table S2). More information on the specimens can again be found on the website of the KIK-IRPA lab (http://c14.kikirpa.be, Van Strydonck and De Roock 2011).

All human and animal samples have been prepared in the KIK. Collagen was extracted following Longin (1971), but using a preparation line adapted for (small) accelerator mass spectrometry (AMS) samples. A supplementary $\mathrm{NaOH}$ step was added. Graphite was prepared using a $\mathrm{Fe} / \mathrm{H}_{2}$ reaction (see Van Strydonck and van der Borg 1990-1991) and measured at Utrecht (lab code UtC) or Kiel (lab code KIA). Samples with RICH and IRPA codes were prepared and analyzed at the KIK, respectively, using AMS and $\beta$-counting. Except for some of the earliest analyses, all samples have been quality checked in terms of collagen percentage and C:N values (following DeNiro 1985; van Klinken 1999, see online-only supplemental file).

Carbon and nitrogen stable isotope compositions were measured as the ratios of the heavier isotopes to the lighter isotopes $\left({ }^{13} \mathrm{C} /{ }^{12} \mathrm{C}\right.$ or $\left.{ }^{15} \mathrm{~N} /{ }^{14} \mathrm{~N}\right)$ and are reported in delta $(\delta)$ notation as parts per thousand (\%o), where $\delta^{13} \mathrm{C}$ or $\delta^{15} \mathrm{~N}=\left(\left[\mathrm{R}_{\text {sample }} / \mathrm{R}_{\text {standard }}\right]-1\right) \times 1000 \%$, and $\mathrm{R}$ is ${ }^{13} \mathrm{C} /{ }^{12} \mathrm{C}$ or ${ }^{15} \mathrm{~N} /{ }^{14} \mathrm{~N}$, relative to internationally defined standards for carbon (Vienna Pee Dee Belemnite, VPDB) and 


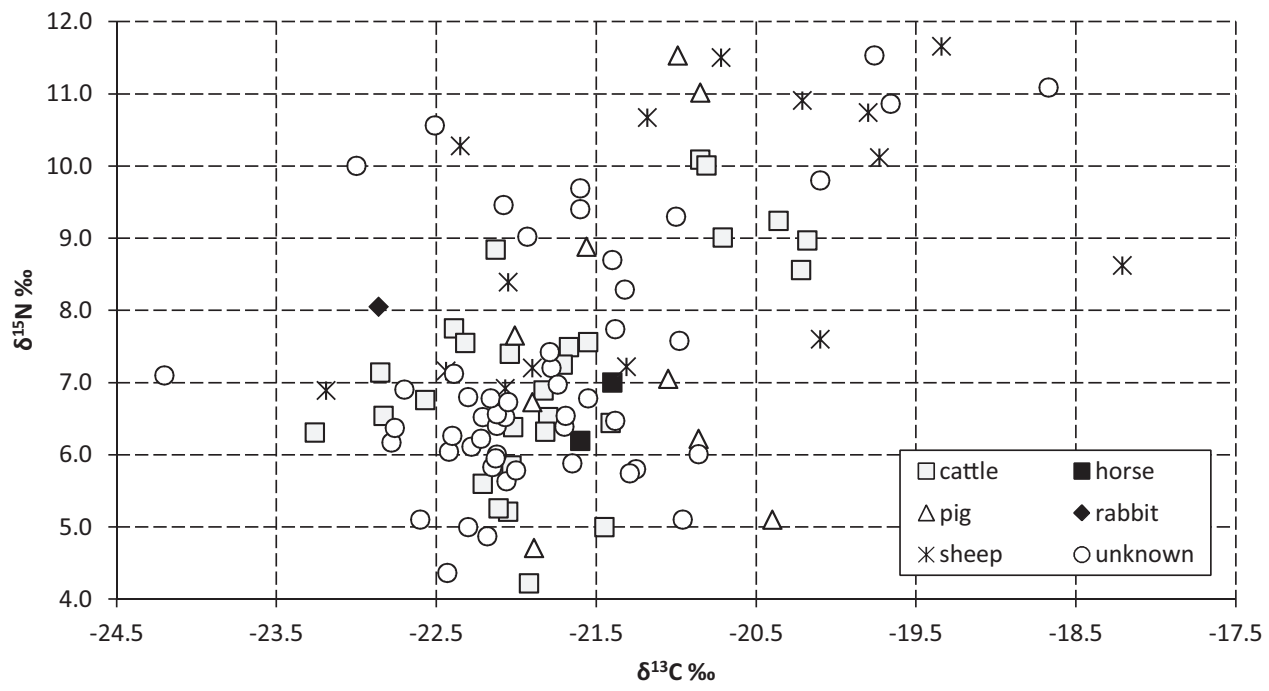

Figure 2 Stable isotope $\left(\delta^{13} \mathrm{C}\right.$ and $\left.\delta^{15} \mathrm{~N}\right)$ data for terrestrial domestic mammals from archaeological sites from Belgium $(n=107)$.

nitrogen (Ambient Inhalable Reservoir, AIR). Analyses were performed in duplicate on a Thermo Flash EA/HT elemental analyzer, coupled to a Thermo DeltaV Advantage isotope ratio mass spectrometer via Conflo IV interface (ThermoFisher Scientific, Bremen, Germany). Standards used were IAEA-N1, IAEA-C6, and internally calibrated acetanilide. Analytical precision was smaller than $0.25 \%$ for both $\delta^{13} \mathrm{C}$ and $\delta^{15} \mathrm{~N}$ based on multiple measurements.

\section{RESULTS AND DISCUSSION}

The stable isotope data for the terrestrial domestic mammals are presented in Figure 2. For $\delta^{13} \mathrm{C}$, a minimum value of $-24.2 \%$ was observed and a maximum of $-18.2 \%$. The average of the 107 measurements is $-21.6 \%$ with a standard deviation of $1.0 \%$. For $\delta^{15} \mathrm{~N}$, the values are $4.2 \%$ ( $\mathrm{min}$.), $11.7 \%$ (max.) and $7.5 \pm 1.8 \%$ (average and standard deviation). Clearly, variation is wide, a pattern that must not only be related with different land use and changes in animal husbandry through time and per region (Ervynck et al. 2007 for pigs; Müldner et al. 2014 for sheep), but that can even be observed within local populations (Ervynck et al. 2003 for cattle; Müldner et al. 2014 for sheep). In general, differences per species are not clear from this data set, implying that pigs, although often considered to be different from herbivores, can remain included within the analysis.

The stable isotope data for the human specimens are presented in Figure 3. For $\delta^{13} \mathrm{C}$, a minimum value of $-21.9 \%$ was observed, and a maximum of $-16.6 \%$. The average of the 234 measurements is $-19.8 \%$ with a standard deviation of $0.6 \%$. For $\delta^{15} \mathrm{~N}$, the values are $6.5 \%$ o (min.), $15.4 \%$ (max.), and $11.1 \pm 1.3 \%$ (average and standard deviation). All data tend to cluster around a single mean, both for $\delta^{13} \mathrm{C}$ and $\delta^{15} \mathrm{~N}$ (Figures 4 and 5). Still, the variation is large, a pattern that most probably must be explained by the variation in terrestrial animal food products (see Figure 2), without doubt at their turn reflecting a large variation in the isotope values of terrestrial plant products. Furthermore, the input of freshwater and marine products must be taken into account, although it remains unknown how important that contribution was (see below). 


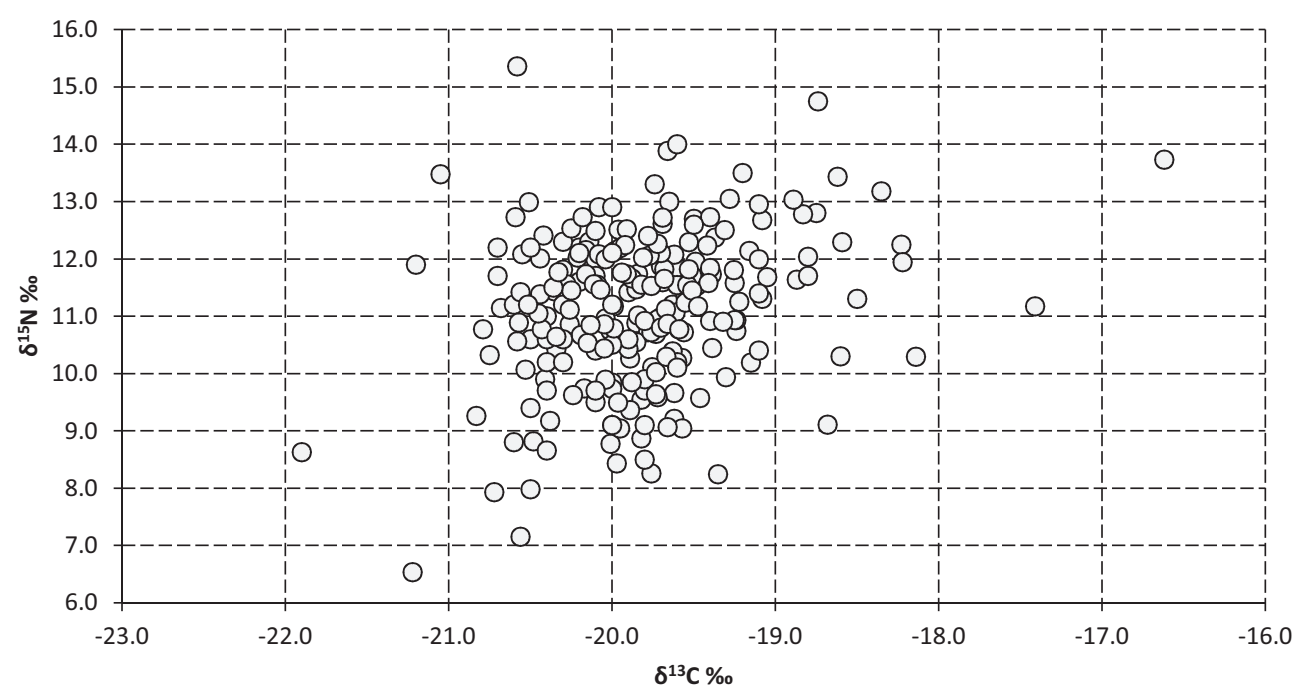

Figure 3 Stable isotope $\left(\delta^{13} \mathrm{C}\right.$ and $\left.\delta^{15} \mathrm{~N}\right)$ data for human remains from Belgian archaeological sites from the historical period $(n=234)$.

Compared to the data of the terrestrial domestic mammals (Figure 6), the human isotope measurements seem to indicate a mixed diet of terrestrial plant and animal products (see Müldner 2009: Figure 16.1). Most indicative is the difference in the average $\delta^{15} \mathrm{~N}$ values of only $3.5 \%$, which represents a single trophic shift in the terrestrial food chain (Post 2002). Of course, it remains problematic to compare the averages of data sets showing a very wide variation, but, in general, indications for a meaningful input of freshwater or marine fish seem to be absent. Even when a mixture of freshwater and marine fish products would produce a $\delta^{13} \mathrm{C}$ signal comparable to that of a diet entirely composed of terrestrial components, the input of fish should reveal itself by higher $\delta^{15} \mathrm{~N}$ values, in any case more elevated than what is predicted by a single trophic shift.

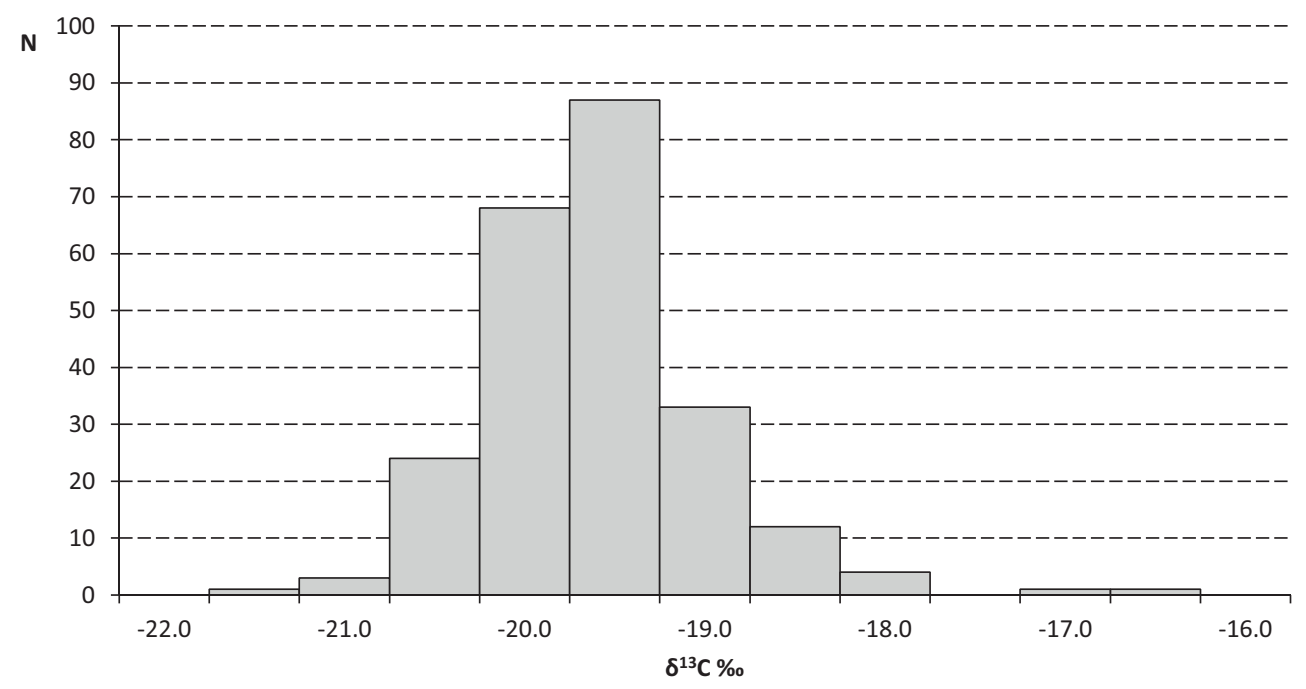

Figure 4 Frequency distribution of the human $\delta^{13} \mathrm{C}$ data represented in Figure $3(n=234)$ 


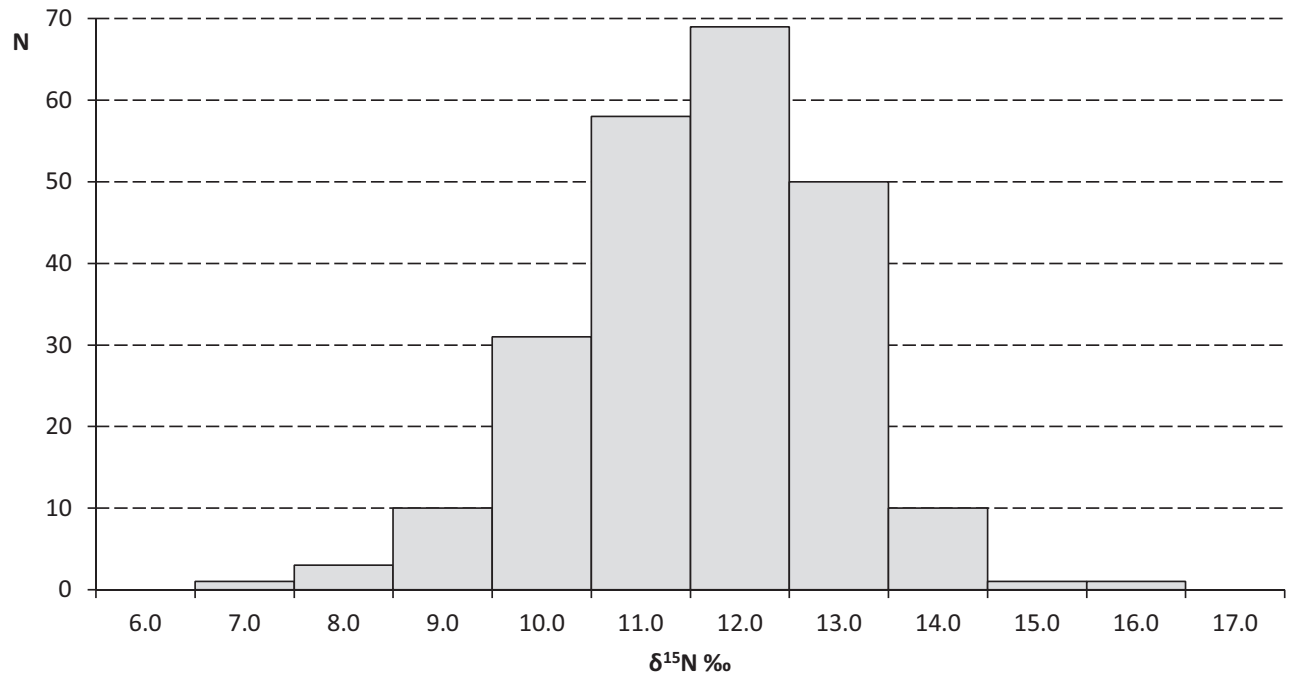

Figure 5 Frequency distribution of the human $\delta^{15} \mathrm{~N}$ data represented in Figure $3(n=234)$

When humans would have been present, who regularly included marine fish products into their diet, data points should show up with higher $\delta^{13} \mathrm{C}$ and $\delta^{15} \mathrm{~N}$ values, causing the data set to show a linear relationship between both parameters (see Müldner 2009, in press). However, such relationship is certainly not corroborated by the data presented in Figure 3. The linear regression equation between the parameters $\left(y=0.5742 x+22.512\right.$, with $x=\delta^{13} \mathrm{C}$ and $\left.y=\delta^{15} \mathrm{~N}\right)$ only yielded a coefficient of determination $\left(R^{2}\right)$ of 0.0708 .

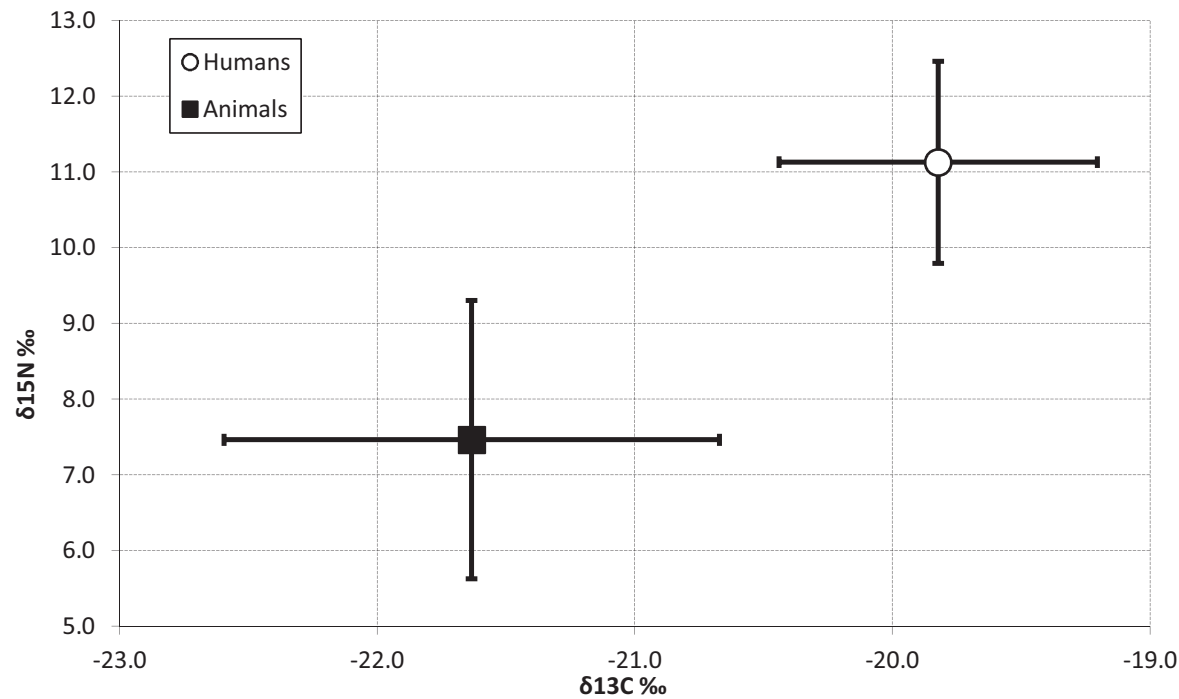

Figure 6 Averages of the stable isotope $\left(\delta^{13} \mathrm{C}\right.$ and $\left.\delta^{15} \mathrm{~N}\right)$ data for the remains of humans and terrestrial domestic mammals from Belgian archaeological sites from the historical period ( $n=234$ for the humans, $n=107$ for the animals, error bar $=1$ standard deviation). 


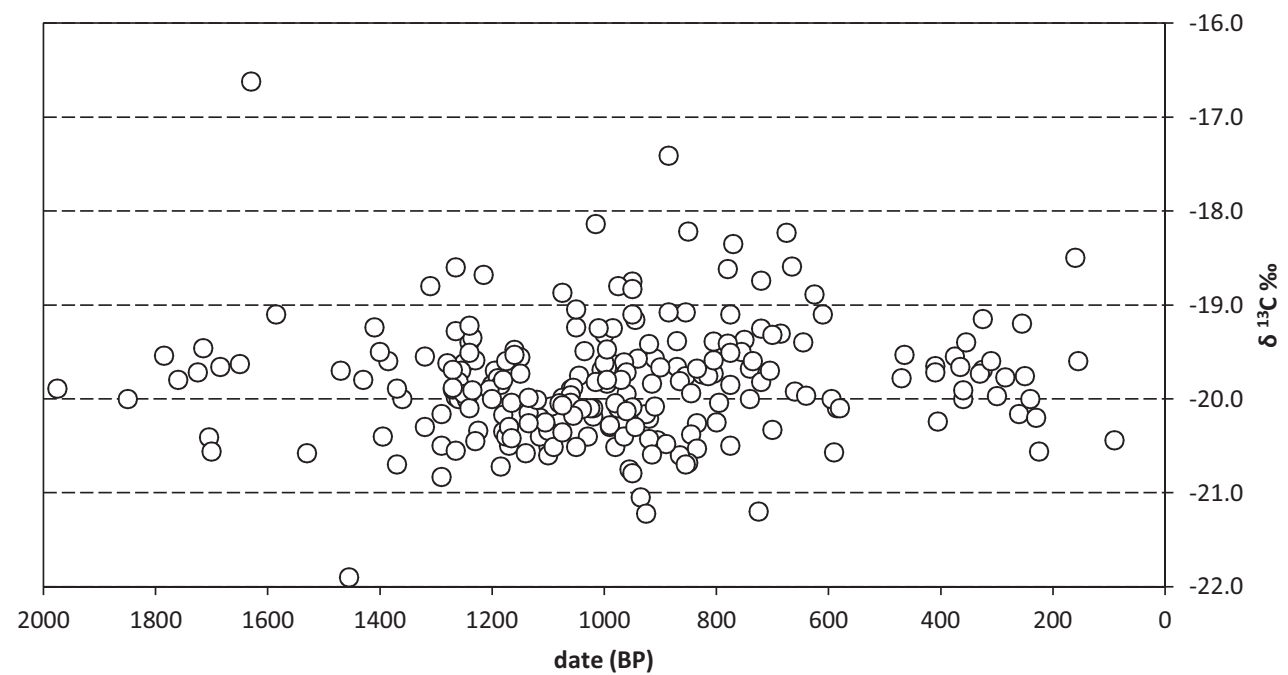

Figure 7 Diachronic comparison of the human $\delta^{13} \mathrm{C}$ data represented in Figure $3\left(n=234\right.$, uncalibrated ${ }^{14} \mathrm{C}$ dates)

This pattern (or better, the lack of any pattern) becomes even clearer when the data are represented diachronically (plotting $\delta^{13} \mathrm{C}$ and $\delta^{15} \mathrm{~N}$ values versus the uncalibrated ${ }^{14} \mathrm{C}$ dates: Figures 7 and 8). Despite the evolution in fish consumption, attested by the archaeozoological data, the isotope signals do not vary significantly through time (linear regressions for $\delta^{13} \mathrm{C}: y=-0.0001 x-19.684$, with $x={ }^{14} \mathrm{C}$ date, $y=\delta^{13} \mathrm{C}, R^{2}=0.0061$; for $\delta^{15} \mathrm{~N}: y=-0.0007 x+11.8$, with $x={ }^{14} \mathrm{C}$ date, $y=\delta^{15} \mathrm{~N}$, $\left.R^{2}=0.0306\right)$. The same is true when only the data from a single site are selected, as an attempt to rule out any noise possibly due to geographical variation. The 49 human specimens from Tongeren within the data set (Roman inhumations, and early- to post-Medieval burials from the Church of

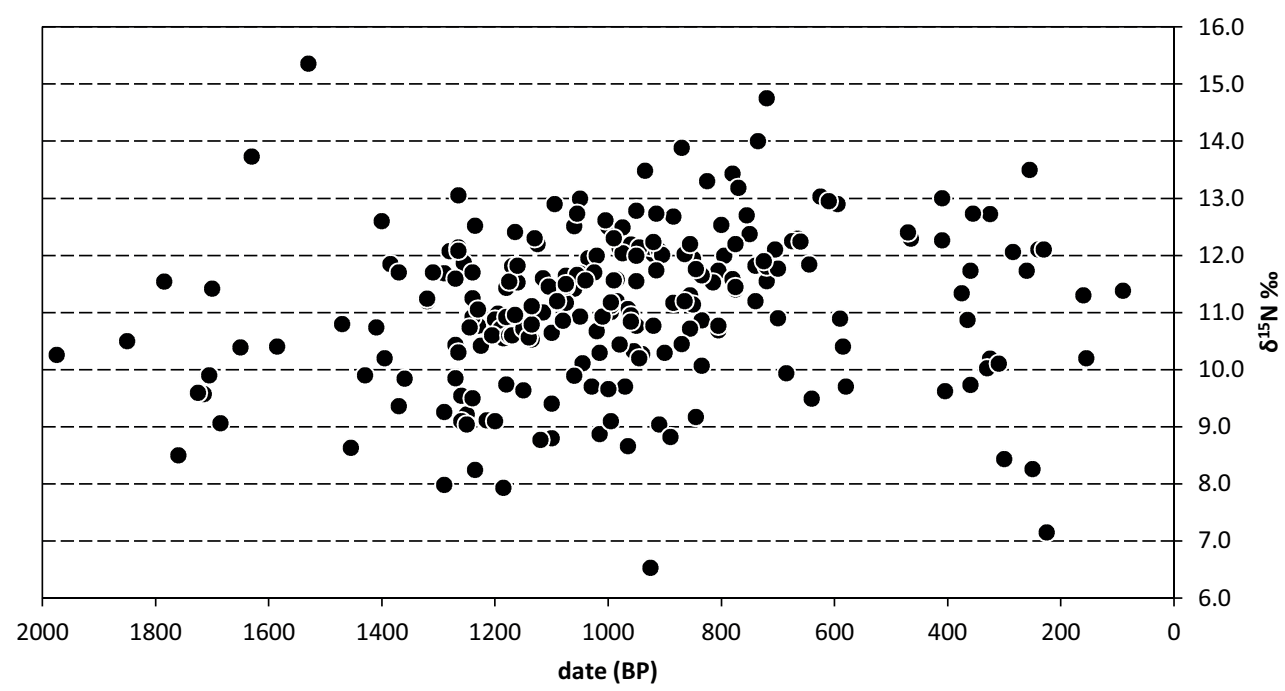

Figure 8 Diachronic comparison of the human $\delta^{15} \mathrm{~N}$ data represented in Figure $3\left(n=234\right.$, uncalibrated ${ }^{14} \mathrm{C}$ dates) 
Our Lady), representing almost $2000 \mathrm{yr}$ of food consumption, do indeed not show any meaningful diachronic trends in their stable isotope signals at all (linear regressions for $\delta^{13} \mathrm{C}: y=0.0005 x-$ 20.484, with $x={ }^{14} \mathrm{C}$ date, $y=\delta^{13} \mathrm{C}, R^{2}=0.064$; for $\delta^{15} \mathrm{~N}: y=-0.0002 x+11.084$, with $x={ }^{14} \mathrm{C}$ date, $\left.y=\delta^{15} \mathrm{~N}, R^{2}=0.0044\right)$.

In general, the rise in seafish consumption, the shift from herring and flatfish (lower in the food chain) to gadids (higher in the food chain), and the growing importance of cod (a carnivore, thus characterized by elevated isotope values: see Fuller et al. 2012) are not reflected in the isotope diagrams. These observations inevitably lead to the conclusion that freshwater or marine fish have never played a dominant role in human protein uptake throughout the last 2 millennia (despite the evolution in fish consumption attested by the archaeozoological data). Protein must have been sufficiently found in the meat of terrestrial animals or in plants such as pulses. Additionally, any indication for an impact of other food products with specific isotope values, such as $\mathrm{C}_{4}$ plants (millet (Panicum miliaceum) in older times, potato (Solanum tuberosum) and maize (Zea mays) in the younger periods), has not been found.

Similar results, i.e. demonstrating a lack of importance of fish products, have been obtained in other case studies, e.g. from Medieval Poland (Reitsema et al. 2010) or Roman Iron Age Denmark (Jørkov et al. 2010), and, to a lesser extent, Medieval Denmark (Yoder 2010). In contrast, studies from the UK have shown a clear diachronic isotopic shift in human remains through the Middle Ages, reflecting a rise in seafish consumption (Müldner 2009, in press). The data set from the UK clearly shows the expected linear relationship between $\delta^{13} \mathrm{C}$ and $\delta^{15} \mathrm{~N}$ values produced by individuals consuming diets with varying contributions of marine fish.

In fact, Belgian archaeology has also produced samples of human isotope data with elevated $\delta^{13} \mathrm{C}$ and $\delta^{15} \mathrm{~N}$ values, possibly illustrating a high intake of marine products. They have not been included in the present survey because no ${ }^{14} \mathrm{C}$ dates were available from the skeletons. A 16th-18th century $\mathrm{AD}$ sample from a mixed lay and monastic burial ground at Aalst (province of East-Flanders) did show elevated isotope values in a majority of the male skeletons $\left(\delta^{13} \mathrm{C}:-19.4 \pm 0.6 \%\right.$, $\delta^{15} \mathrm{~N}: 12.3 \pm$ $0.9 \%, n=25$ ) but not in the female samples. This, and the historical context, suggests that mainly monks were the ones consuming more marine fish (Quintelier et al. 2014), an interpretation generally corroborated by historical and archaeozoological data for monastic sites (Ervynck 1997). A 12th-15th century AD sample from a male monastic site near the Flemish coast yielded comparable values of $-19.1 \pm 0.5 \%$ for $\delta^{13} \mathrm{C}$ and $11.1 \pm 0.9 \%$ for $\delta^{15} \mathrm{~N}(n=19$ : Polet and Katzenberg 2003). Unfortunately, given the lack of ${ }^{14} \mathrm{C}$ dates obtained from these Belgian monastic sites, a possible bias through reservoir effects could not be evaluated (e.g. against the historical context, or chronological indications derived from building history or archaeological stratigraphy).

Remarkably, the skeleton from Slijpe, dating too old, showed isotope values (KIA-47728, $\delta^{13} \mathrm{C}$ : $-20.4 \%$, $\delta^{15} \mathrm{~N}: 11.5 \%$ ) comparable to the human data set in general, and to the samples from Vulferus (KIA-21809, $\delta^{13} \mathrm{C}:-19.2 \%$, $\delta^{15} \mathrm{~N}: 10.9 \%$ ) and Saint-Bavo (KIA-20205, $\delta^{13} \mathrm{C}:-19.2 \%$, $\delta^{15} \mathrm{~N}: 10.7 \%$ ), the latter two yielding dates that fit well with the historical information available. For the moment, this phenomenon remains unresolved.

Finally, in these proceedings, Boudin et al. (2014) point to dating problems with three Medieval skeletons from Belgium, possibly showing a clear freshwater reservoir effect. These individuals, two bishops and a saint, could well have had diets that differed drastically from the populations represented by the present survey. 
Dating Human Remains from Historical Period in Belgium

\section{CONCLUSION}

In the case of Belgium, the general outcome of the present survey of stable isotope data from human remains, dating from the last 2 millennia, seems to be that reservoir effects can be ignored, at least when nonclerical sites (or individuals) are investigated (although that restriction needs to be further evaluated by more research). Otherwise stated, even when reservoir effects were present, the bias they induced will have fallen within the error margins of the ${ }^{14} \mathrm{C}$ dates obtained. This conclusion was not expected at all, given the striking diachronic changes in human diet attested by archaeozoological investigations, and corroborated (for the Middle Ages and younger periods) by historical evidence. In any case, the isotope signals, from a sample set representing the last 2 decades, generally do indicate a lack of importance of fish products for the diets of the humans investigated.

\section{REFERENCES}

Asaert G. 1980. Scheepvaart en visserij. In: Algemene Geschiedenis der Nederlanden 4. Haarlem: Fibula-Van Dishoeck. p 128-34.

Boelmans Kranenburg HAH. 1979. Visserij in de Zuidelijke Nederlanden 1650-1795. In: Algemene Geschiedenis der Nederlanden 8. Haarlem: FibulaVan Dishoeck. p 261-4.

Boelmans Kranenburg HAH. 1980. Visserij in de Zuidelijke Nederlanden 1580-1650. In: Algemene Geschiedenis der Nederlanden 7. Haarlem: FibulaVan Dishoeck. p 170-1.

Boudin M, Van Strydonck M. 2010. Dateren van beenderen met de radiokoolstofmethode. In: Laleman MC, editor. Onder het Sint-Pietersplein. Gent. Van hoogadellijke begraafplaats tot parking. Ghent: Snoeck. p 102-13.

Boudin M, Boeckx P, Vandenabeele P, Van Strydonck M. 2014. An archaeological mystery revealed by radiocarbon dating of cross-flow nanofiltrated amino acids derived from bone collagen, silk, and hair: case study of the bishops Baldwin I and Radbot II from Noyon-Tournai. Radiocarbon, these proceedings.

Bronk Ramsey C. 2001. Development of the radiocarbon calibration program. Radiocarbon 43(2A):355-63.

DeNiro MJ. 1985. Postmortem preservation and alteration of in vivo bone collagen isotope ratios in relation to palaeodietary reconstruction. Nature 317(6040):806-9.

Dobney K, Ervynck A. 2007. To fish or not to fish? Evidence for the possible avoidance of fish consumption during the Iron Age around the North Sea. In: Haselgrove C, Moore $\mathrm{T}$, editors. The Later Iron Age in Britain and Beyond. Oxford: Oxbow Books. p 403-18.

Ervynck A. 1997. Following the rule? Fish and meat consumption in monastic communities in Flanders (Belgium). In: De Boe G, Verhaeghe F, editors. Environment and Subsistence in Medieval Europe. Papers of the 'Medieval Europe Brugge 1997.' Conference Volume 9. Brussels: Instituut voor het Archeologisch Patrimonium. p 67-81.

Ervynck A, Hillewaert B, Maes A, Van Strydonck M. 2003. Tanning and horn-working at late- and post-medieval Brugge: the organic evidence. In:
Murphy P, Wiltshire P, editors. The Environmental Archaeology of Industry. Oxford: Oxbow Books. p 60-70.

Ervynck A, Van Neer W, Pieters M. 2004. How the North was won (and lost again). Historical and archaeological data on the exploitation of the North Atlantic by the Flemish fishery. In: Housley RA, Coles $\mathrm{G}$, editors. Atlantic Connections and Adaptations. Economies, Environments and Subsistence in Lands Bordering the North Atlantic. Oxford: Oxbow. p 230-39.

Ervynck A, Lentacker A, Müldner G, Richards M, Dobney K. 2007. An investigation into the transition from forest dwelling pigs to farm animals in medieval Flanders, Belgium.' In: Albarella U, Dobney K, Ervynck A, Rowley-Conwy P, editors. Pigs \& Humans. 10,000 Years of Interaction. Oxford: Oxford University Press. p 171-93.

Fischer A, Heinemeier J. 2003. Freshwater reservoir effect in ${ }^{14} \mathrm{C}$ dates of food residue on pottery. Radiocarbon 45(3):449-66.

Fuller BT, Müldner G, Van Neer W, Ervynck A, Richards MP. 2012. Carbon and nitrogen stable isotope ratio analysis of freshwater, brackish and marine fish from Belgian archaeological sites (1st and 2nd millennium AD). Journal of Analytical Atomic Spectrometry 27:807-20.

Jørkov MLS, Jørgensen L, Lynnerup N. 2010. Uniform diet in a diverse society. Revealing new dietary evidence of the Danish Roman Iron Age based on stable isotope analysis. American Journal of Physical Anthropology 143(4):523-33.

Lanting JN, van der Plicht J. 1998. Reservoir effects and apparent ${ }^{14} \mathrm{C}$ ages. The Journal of Irish Archaeology IX:151-65.

Lee-Thorp JA. 2008. On isotopes and old bones. Archaeometry 50(6):925-50.

Longin R. 1971. New method of collagen extraction for radiocarbon dating. Nature 230(5291):241-2.

Müldner GH. 2009. Investigating medieval diet and society by stable isotope analysis of human bone. In: Gilchrist R, Reynolds A, editors. Reflections: 50 Years of Medieval Archaeology. Leeds: Maney. p 327-46.

Müldner G. In press. Marine fish consumption in medi- 
eval England - The isotope perspective. In: Barrett $\mathrm{J}$, Orton D, editors. Cod and Consequences. The Archaeology and History of Medieval Sea Fishing. Oxford: Oxbow.

Müldner G, Britton K, Ervynck A. 2014. Inferring animal husbandry strategies in coastal zones through stable isotope analysis: new evidence from the Flemish coastal plain (Belgium, 1st-15th century AD). Journal of Archaeological Science 41:322-32.

Polet C, Katzenberg MA. 2003. Reconstruction of the diet in a mediaeval monastic community from the coast of Belgium. Journal of Archaeological Science 30(5):525-33.

Post DM. 2002. Using stable isotopes to estimate trophic position: models, methods, and assumptions. Ecology 83(3):703-18.

Quintelier K, Ervynck A, Müldner G, Van Neer W, Richards MP, Fuller BT. 2014. Isotopic examination of links between diet, social differentiation, and DISH at the post-medieval Carmelite Friary of Aalst, Belgium. American Journal of Physical Anthropology 153(2):203-13.

Reimer PJ, Baillie MGL, Bard E, Bayliss A, Beck JW, Blackwell PG, Bronk Ramsey C, Buck CE, Burr GS, Edwards RL, Friedrich M, Grootes PM, Guilderson TP, Hajdas I, Heaton TJ, Hogg AG, Hughen KA, Kaiser KF, Kromer B, McCormac FG, Manning SW, Reimer RW, Richards DA, Southon JR, Talamo S, Turney CSM, van der Plicht J, Weyhenmeyer CE. 2009. IntCa109 and Marine09 radiocarbon age calibration curves, $0-50,000$ years cal BP. Radiocarbon 51(4):1111-50.

Reitsema LJ, Crews DE, Polcyn M. 2010. Preliminary evidence for medieval Polish diet from carbon and nitrogen stable isotopes. Journal of Archaeological Science 37(7):1413-23.

Smet J, Maesen K, De Gryse J, Pieters T. 2012. Archeologisch onderzoek dorpscentrum Slype. Ruben Willaert Rapport 7. Bruges: Ruben Willaert.

Stuiver M, Braziunas TF. 1993. Modeling atmospheric ${ }^{14} \mathrm{C}$ influences and ${ }^{14} \mathrm{C}$ ages of marine samples to 10,000 BC. Radiocarbon 35(1):137-91.

van Klinken GJ. 1999. Bone collagen quality indicators for palaeodietary and radiocarbon measurements. Journal of Archaeological Science 26(6):687-95.

Van Neer W, Ervynck A. 2006. The zooarchaeological reconstruction of the development of the exploitation of the sea: a status quaestionis for Flanders. In: Pieters M, Verhaeghe F, Gevaert G, editors. Fishery, Trade and Piracy. Fishermen and Fishermen's Settlements in and around the North Sea Area in the Middle Ages and Later. Archeologie in Vlaanderen Monografie 6. Brussels: Flemish Heritage Institute. p 95-103.

Van Neer W, Ervynck A, Monsieur P. 2010. Fish bones and amphorae: evidence for the production and consumption of salted fish products outside the Mediterranean region. Journal of Roman Archaeology 23(1):161-95

Van Neer W, Ervynck A, Wouters W, Muylaert L, Barrett J, Richards M, Johnstone C. In press. The rise of seafish consumption in inland Flanders (Belgium). In: Barrett J, Orton D, editors. Cod and Consequences. The Archaeology and History of Medieval Sea Fishing. Oxford: Oxbow.

Van Strydonck M, De Roock E. 2011. Royal Institute for Cultural Heritage web-based radiocarbon database. Radiocarbon 53(2):367-70.

Van Strydonck M, van der Borg K. 1990-1991. The construction of a preparation line for AMS-targets at the Royal Institute for Cultural Heritage Brussels. Bulletin of the Royal Institute for Cultural Heritage 23:228-34.

Van Strydonck M, Ervynck A, Vandenbruaene M, Boudin M. 2006. Relieken: echt of vals? Leuven: Davidsfonds.

Van Strydonck M, Ervynck A, Vandenbruaene M, Boudin M. 2009. Anthropology and ${ }^{14} \mathrm{C}$ analysis of skeletal remains from relic shrines: an unexpected source of information for Medieval archaeology. Radiocarbon 51(2):569-77.

Van Uytven R. 1979. Visserij in de Zuidelijke Nederlanden. In: Algemene Geschiedenis der Nederlanden 6. Haarlem: Fibula-Van Dishoeck. p 138-44.

Yoder C. 2010. Diet in medieval Denmark: a regional and temporal comparison. Journal of Archaeological Science 37(9):2224-36. 